\title{
MENINGKATKAN KEMAMPUAN PEMAHAMAN DAN KOMUNIKASI MATEMATIK SISWA SMK MELALUI PENDEKATAN KONTEKSTUAL DAN STRATEGI FORMULATE-SHARE-LISTEN-CREATE (FSLC)
}

\author{
Oleh: \\ Dian Anggraeni ${ }^{1}$ \\ Utari Sumarmo $^{2)}$ \\ ${ }^{1}$ Guru SMK di Bandung \\ ${ }^{2}$ STKIP Siliwangi Bandung, utari.sumarmo@yahoo.co.id
}

\begin{abstract}
Makalah ini melaporkan temuan satu eksperimen dengan disain pretest-postest dengan kelompok kontrol dan menerapkan pendekatan kontekstual dan strategi formulate-sharelisten-create (FSLC), untuk menelaah kemampuan pemahaman dan komunikasi matematik siswa SMK. Subyek penelitian ini adalah 80 siswa SMK program keahlian pemasaran di Bandung. Instrumen penelitian terdiri dari tes kemampuan pemahaman dan komunikasi matematik serta disposisi matematik. Berdasarkan analisis data menggunakan SPSS 16.0 dan Microsoft Excel 2010, penelitian menemukan: Pencapaian dan peningkatan kemampuan pemahaman dan komunikasi matematik siswa yang memperoleh pendekatan kontekstual dan strategi formulate-share-listen-create (FSLC) lebih baik daripada pencapaian dan peningkatan kemampuan siswa yang memperoleh pembelajaran konvensional. Penelitian juga menemukan adanya asosiasi sedang antara kemampuan pemahaman dan komunikasi matematik, dan siswa menunjukkan disposisi matematik yang positif terhadap pendekatan kontekstual dan strategi formulate-share-listen-create (FSLC)
\end{abstract}

Kata Kunci : pendekatan kontekstual, strategi formulate-share-listen-create, pemahaman dan komunikasi matematik, disposisi matematik

This paper reports the findings from an experimental prettest-posttest control group design conducted by using contextual approach and formulate-share-listen-create (FSLC) strategy to investigate students' mathematical understanding and communication abilities. The study involved 80 grade-11 students from SMK of marketing field program in Bandung. The instrumens of this study are mathematical undestanding test, mathematical communication test, and mathematical disposistion scale. By using SPSS 16.0 and Microsoft Excel 2010, the study found the contextual approach and formulate-share-listen-create (FSLC) strategy was able to improve students' mathematical understanding and mathematical communication abilities better than that of conventional approach. Students' mathematical understanding and communication abilities were classified as mediocore. Furthermore, the study found there was medium association between mathematical understanding and mathematical communication abilities, and students performed positive disposition on contextual approach and formulate-share-listen-create (FSLC) strategy.

Key words : contextual approach, formulate strategies, share, listen, create, understanding and mathematical communication, mathematical disposition 


\section{Latar Belakang}

Matematika merupakan satu mata pelajaran yang termasuk dalam kelompok adaptif, dalam Kurikulum SMK (KTSP, 2006). Kemampuan pemahaman dan komunikasi matematik dan disposisi matematis merupakan kemampuan dan disposisi yang perlu dikembangkan pada siswa SMK karena sesuai dengan tujuan pembelajaran matematika SMK antara lain: 1) Memahami konsep matematika, menjelaskan keterkaitan antarkonsep dan mengaplikasikan konsep atau algoritma secara luwes, akurat, efisien dan tepat dalam pemecahan masalah, dan 2) Mengomunikasikan gagasan dengan simbol, tabel, diagram atau media lain untuk memperjelas keadaan atau masalah, 3) Menghargai kegunaan matematika dalam kehidupan serta memiliki rasa ingin tahu, perhatian, dan minat dalam mempelajari matematika serta sikap ulet dan percaya diri dalam pemecahan masalah.

Merujuk pendapat Polya dan Skemp, Sumarmo (2010) mngemukakan terdapat dua tingkat pemahaman matematik yaitu tingkat rendah misalnya pemahaman mekanikal dan pemahaman komputasional, dan pemahaman tingkat tinggi misalnya pemahaman relasional dan pemahaman rasional. NCTM (Riyanti, 2011) merinci pemahaman matematik meliputi kemampuan: mendefinisikan konsep secara verbal dan tulisan; membuat contoh dan non contoh; mempresentasikan suatu konsep dengan model, diagram dan simbol; mengubah suatu bentuk representasi ke bentuk representasi yang lain; mengenal berbagai makna dan interpretasi konsep; mengidentifikasi sifat-sifat suatu konsep dan mengenal syarat-syarat yang menentukan suatu konsep; membandingkan dan membedakan konsep-konsep.

Sumarmo (2010) merangkum pendapat beberapa pakar dan NCTM dan mengidentifikasi beberapa kemampuan komunikasi matematik antara lain: menyatakan suatu situasi, ke dalam bentuk gambar, diagram, bahasa, simbol, ekspresi atau model matematik; dan sebaliknya menyatakan gambar, diagram, bahasa, simbol, ekspresi atau model matematik ke dalam bahasa sendiri. Komponen ketiga dalam tujuan pemebalajaran matematika di SMK, pada dasarnya melukiskan disposisi matematik yaitu adalah keinginan, kesadaran, dan dedikasi yang kuat pada diri siswa untuk belajar matematika dan melaksanakan berbagai kegiatan matematika.

Memperhatikan penting pemilikan kemampuan pemahaman dan komunikasi untuk siswa SMK, maka guru matematika SMK perlu merancang dan melaksanakan pembelajaran matematika inovatif yang membantu siswa mencapai hail belajar matematika yang lebih baik. Johnson dan Smith (1991), menawarkan strategi formulate-share-listen-create (FSLC) dengan memodifikasi strategi pembelajaran think-pair-share (TPS). Strategi FSLC adalah strategi pembelajaran dalam kelompok kecil yang berpasangan yang memuat langkah-langkah: memformulasikan pendapat masing-masing, berbagi pendapat dengan teman pasangannya, mendengarkan dan mencatat kesamaan dan perbedaan pendapat 
pasangan yang lainnya, dan menyusun kesimpulan dengan cara menggabungkan ideide terbaik mereka. Studi Sabilulungan (2008), dan Setiadi (2010) dengan menerapkan strategi think-pair-share, dan studi Emay (2011) dengan mengimplementasikan strategi formulate-share-listen-create melaporkan bahwa kemampuan pemahaman dan komunikasi matematis siswa SMP lebih baik daripada kemampuan siswa yang memperoleh pembelajaran konvensional. Dua studi lain terhadap siswa SMK, Kurniawan (2010), dan Lestari (2009) melaporkan berturutturut bahwa kemampuan pemahanan dan pemecahan masalah matematis dan kemampuan pemahanan dan koneksi matematis siswa yang memperoleh pembelajaran kontekstual lebih baik daripada kemampuan matematik tadi pada siswa yang mendapat pembelajaran konvensional. Studi-studi tersebut melukiskan bahwa pembelajaran matematika yang inovatif memberi peluang lebih besar kepada siswa untuk mencapai hasil belajar matematik yang lebih baik.

Analisis terhadap kemampuan matematis dan temuan beberapa studi yang telah dikemukakan, mendorong peneliti melakukan studi dengan mengimplementasikan pembelajaran kontekstual dan strategi formulate-share-listen-create (FSLC) untuk menelaah kemampuan pemahaman dan komunikasi matematis siswa SMK.

\section{Telaah Kepustakaan}

\section{Pemahaman, Komunikasi, dan Disposisi Matematis}

Matematika merupakan satu mata pelajaran yang termasuk dalam kelompok adaptif, dalam Kurikulum SMK (KTSP, 2006). Tujuan pembelajaran matematika SMK adalah agar siswa memiliki kemampuan dalam: 1) Memahami konsep matematika, menjelaskan keterkaitan antarkonsep dan mengaplikasikan konsep atau algoritma secara luwes, akurat, efisien dan tepat dalam pemecahan masalah, 2) Menggunakan penalaran pada pola dan sifat, melakukan manipulasi matematika dalam membuat generalisasi, menyusun bukti, atau menjelaskan gagasan dan pernyataan matematika, 3) Memecahkan masalah yang meliputi kemampuan memahami masalah, merancang model matematika, menyelesaikan model dan menafsirkan solusi yang diperoleh, 4) Mengomunikasikan gagasan dengan simbol, tabel, diagram atau media lain untuk memperjelas keadaan atau masalah, 5) Menghargai kegunaan matematika dalam kehidupan serta memiliki rasa ingin tahu, perhatian, dan minat dalam mempelajari matematika serta sikap ulet dan percaya diri dalam pemecahan masalah, serta 6) Menalar secara logis dan kritis serta mengembangkan aktivitas kreatif dalam memecahkan masalah dan mengomunikasikan ide, serta menerapkan matematika dalam setiap program keahlian.

Merujuk tujuan pembelajaran matematika di atas, pada dasarnya kemampuan pemahaman, komunikasi, dan disposisi matematis yang tercantum pada butir 1, butir 4, dan butir 5 merupakan dua kemampuan dan diposisi esensial yang perlu dikembangkan pada siswa SMK. Istilah pemahaman merupakan jenjang kognitif 
kedua dalam taksonomi Bloom yang menggambarkan penguasaan menggunakan kaidah yang relevan tanpa menghubungkannya dengan ide-ide lain dan segala implikasinya. Tingkat pemahaman tersebut setara dengan tingkat pemahaman instrumental (Skemp dalam Sumarmo, 2010) yaitu dapat menghapal rumus dan mengikuti urutan pengerjaan dan algoritma saja; tingkat pemahaman tersebut juga setara dengan pemahaman mekanikal (Polya dalam Sumarmo, 2010) yaitu melaksanakan perhitungan rutin atau sederhana, mengerjakan sesuatu secara algoritmik;. Tingkat pemahaman yang lebih tinggi dari kedua jenis pemahaman di atas adalah pemahaman relasional (Skemp dalam Sumarmo, 2010) atau pemahaman rasional (Polya dalam Sumarmo, 2010) yaitu dapat menerapkan rumus secara bermakna dan disertai alasan, mengkaitkan satu idea dengan idea lain, dan membuktikan kebenaran suatu rumus.

Sebagai contoh, siswa yang memiliki pemahaman instrumental atau mekanikal dapat menyelesaikan persamaan kuadrat $2 x^{2}-3 x+1=0$ dengan menggunakan aturan abc, namun ia gagal menerapkan rumus abc dalam soal $b x^{2}+c x+a=0$. Pengertian pemahaman matematik yang lebih rinci dikemukakan oleh NCTM sebagai berikut: mendefinisikan konsep secara verbal dan tulisan; membuat contoh dan non contoh; mempresentasikan suatu konsep dengan model, diagram dan simbol; mengubah suatu bentuk representasi ke bentuk representasi yang lain; mengenal berbagai makna dan interpretasi konsep; mengidentifikasi sifat-sifat suatu konsep dan mengenal syarat-syarat yang menentukan suatu konsep; membandingkan dan membedakan konsep-konsep. Jenjang koginitif pemahaman di atas tergolong pada pemahaman yang tinggi yaitu pemahaman relasional atau pemahaman rasional.

Sumarmo (2010) merangkum pendapat beberapa pakar dan NCTM dan mengidentifikasi beberapa kemampuan komunikasi matematik antara lain: a) Menyatakan suatu situasi, ke dalam bentuk gambar, diagram, bahasa, simbol, ekspresi atau model matematik; b) Menyatakan gambar, diagram, bahasa, simbol, ekspresi atau model matematik ke dalam bahasa sendiri; c) Mendengarkan, berdiskusi, menulis matematika; d) Membaca suatu presentasi matematik disertai pemahaman; e) Mengungkapkan kembali suatu uraian matematik dalam bahasanya sendiri; dan 7) Menyusun pertanyaan tentang matematika.

Komponen kelima dan keenam dalam tujuan pembelajaran matematika di SMK, pada dasarnya melukiskan disposisi matematik yaitu keinginan, kesadaran, dan dedikasi yang kuat pada diri siswa untuk belajar matematika dan melaksanakan berbagai kegiatan matematika. Sumarmo (2010) merinci indikator disposisi matematik sebagai berikut: a) Menunjukkan antusias dalam belajar matematika; b) Menunjukkan perhatian yang serius dalam belajar matematika; c) Menunjukkan kegigihan dalam menghadapi permasalahan; d) Menunjukkan konsep diri dalam belajar matematika; e) Menunjukkan rasa ingin tahu yang tinggi; f) Menunjukkan kemampuan untuk berbagi pendapat dengan orang lain. Untuk mengungkapkan disposisi matematik siswa, dapat menggunakan skala disposisi model Likert 
dengan pilihan jawaban; sangat setuju, setuju, netral, tidak setuju, sangat tidak setuju, atau dengan pilihan jawaban: sangat sering, sering, kadang-kadang, jarang , dan sangat jarang.

\section{Pembelajaran Kontekstual dan Strategi Formulate-share-listen-create (FSLC)}

Pembelajaran kontekstual merupakan salah satu pembelajaran yang dianjurkan dalam KTSP (2006). Depdiknas (2002) menyatakan pembelajaran kontekstual melibatkan tujuh komponen utama pembelajaran yaitu: kontrukstivisme, menemukan, bertanya, masyarakat belajar, pemodelan, refleksi dan asesmen otentik. Zahorik (Kurniawan, 2010) dan Suherman dkk (2003) menyatakan terdapat lima elemen yang harus diperhatikan dalam pelaksanaan pembelajaran kontekstual yaitu: a) Pengaktifan pengetahuan yang sudah ada; b) Pemerolehan pengetahuan baru dengan cara mempelajari secara keseluruhan dulu, kemudian memperhatikan detilnya; c) Pembentukan pengetahuan dilakukan dengan cara menyusun d) konsep sementara, e) Melakukan sharing kepada orang lain untuk mendapat tanggapan dan f) Berdasarkan tanggapan itu konsep tersebut direvisi dan dikembangkan; g) Mempraktekkan pengetahuan dan pengalaman tersebut; dan h) Melakukan refleksi terhadap strategi pengembangan pengetahuan tersebut.

Born dan De Stefano (Kurniawan, 2010) mengemukakan aktivitas pembelajaran kontekstual yang meliputi:

a) Belajar berbasis masalah: pembelajaran diawali dengan penyajian masalah kontekstual yang menantang untuk memperoleh pemahaman konsep dan kemampuan matematik lainnya

b) Belajar dengan multi kompleks: pembelajaran dilaksanakan sesuai dengan keadaan kondisi sehari-hari atau disimulasikan dan familiar, sehingga pengetahuan yang didapat dari sekolah dapat diaplikasikan di tempat kerja, di rumah, atau di lingkungan masyarakatnya.

c) Belajar mandiri: siswa didorong untuk memiliki kesadaran berpikir, dapat memilih strategi sendiri, dan memelihara motivasi.

d) Penilaian otentik: penilaian terhadap produk dan proses pembelajaran.

e) Masyarakat belajar: belajar berlangsung dalam suatu komunitas belajar yang saling memberi, menerima, dan saling menghargai pendapat orang lain.

Strategi pembelajaran formulate-share-listen-create (FSLC) merupakan bentuk belajar kooperatif dalam kelompok kecil dan merupakan modifikasi dari strategi TPS. Johnson, Johnson dan Smith (1991) mengembangkan strategi FSLC yang meliputi langkah-langkah: a) Formulate : kegiatan mencatat informasi yang berkaitan dengan tugas dan membuat rencana penyelesaian; b) Share: siswa berbagi pendapat dengan pasangannya; c) Listen: tiap pasangan saling mendengar pendapat pasangan lainnya, dan mencatat perbedaan dan persamaan pendapat; d) Create:siswa berdiskusi untuk mencapai kesimpulan. 


\section{Penelitian Yang Relevan}

Beberapa penelitian (Kurniawan, 2010, Lestari, 2009, Nasir, 2008, Sabilulungan 2008, Setiadi, 2010, Sofian, 2011) melaporkan kelebihan pembelajaran kontekstual dari pada pembelajaran konvensional dalam meningkatkan kemampuan matmatik siswa. Studi Nasir (2008) melaporkan kemampuan koneksi dan pemecahan masalah matematik siswa SMA yang berkemampuan rendah melalui pendekatan kontekstual lebih baik dari kemampuan siswa yang mendapat pemebalajaran konvensional.

Kelebihan pembelajaran kontekstual dari pembelajaran konvensional pada subyek siswa SMK, dilaporkan Lestari (2009) dan Kurniawan (2010) berturut-turut mengenai kemampuan pemahaman dan koneksi matematis dan kemampuan pemahaman dan pemecahan masalah matematis. Kemudian, dalam kemampuan pemahaman dan penalaran matematis siswa, Sofian (2011) menemukan hasil yang serupa.

Penelitian lain, Sabilulungan (2008) dan Setiadi (2010) dengan menerapkan belajar kooperatif dengan strategi think-pair-share melaporkan hasil belajar matematis yang lebih baik daripada hasil belajar siswa pada kelas konvensional. Temuan serupa dilaporkan pula dalam studi Emay (2011) yang mengimplemntasikan strategi formulate-share-listen-create mengenai kemampuan pemahaman dan koneksi matematis pada siswa SMP.

\section{Disain dan Instrumen}

Penelitian ini adalah suatu ekaperimen dengan disain pretes-postes dan kelompok kontrol dengan mengimplementasikan pembelajaran kontekstual dan strategi formulate-share-listen-create untuk menelaah kemampuan pemahaman dan komunikasi serta disposisi matematik siswa. Secara lebih rinci, penelitian bertujuan: a) Menelaah pencapaian dan peningkatan kemampuan pemahaman dan komuikasi matematik siswa setelah pembelajaran kontekstual dan strategi formulate-sharelisten-create dan pembelajaran konvensional; b) Menelaah disposisi matematik siswa; c) Memeriksa eksistensi asosiasi antara kemampuan pemahaman dan komunikasi matematik.

Subyek penelitian ini adalah 80 siswa kelas-11 dari satu SMK program Pemasaran. Instrumen penelitian ini adalah: tes bentuk uraian dalam kemampuan pemahaman matematik, dan dalam kemampuan komunikasi matematik, dan skala disposisi matematik. Berikut ini disajikan contoh instrumen dalam penelitian ini. 


\section{Contoh 1: Soal pemahaman matematis}

Daerah yang diarsir di bawah ini merupakan himpunan penyelesaian dari suatu sistem pertidaksamaan.

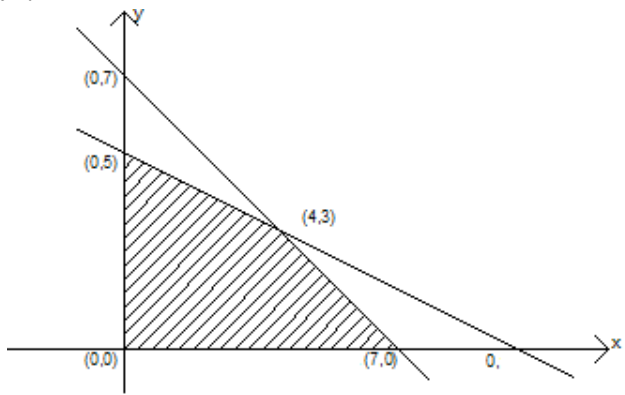

Apakah titik-titik $(1,5),(3,4),(5,2)$ dan $(6,3)$ terletak pada daerah himpunan penyelesaian? Jelaskan!

\section{Contoh 2 : Soal komunikasi matematik}

Daerah yang diarsir di bawah ini merupakan himpunan penyelesaian dari suatu sistem pertidaksamaan. Tentukan sistem pertidaksamaan tersebut!

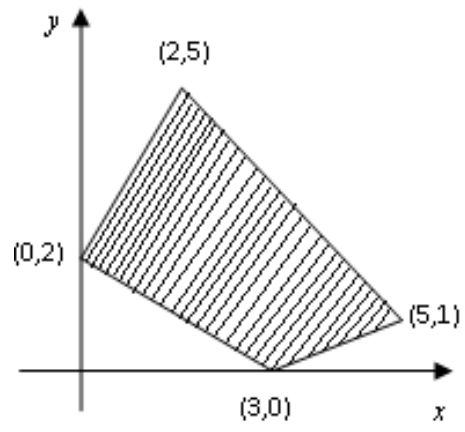

\section{Contoh 3: Soal komunikasi matematik}

Seorang pedagang mempunyai modal $\mathrm{Rp} 480.000$,- ia akan membeli teh jenis A yang harganya $R p$ 6.000,- tiap kotak dan teh jenis B yang harganya $R p$ 8.000,- tiap kotak. Teh ini akan dijual, tiap kotaknya dengan harga $\mathrm{Rp} 9.300$,untuk teh jenis A dan Rp 8.500,- untuk teh jenis B. Lemari tempat menyimpan kedua jenis teh tersebut dapat menampung 70 kotak teh jenis A dan B.

a. Buatlah model matematika yang mengilustrasikan masalah itu!

b. Tentukanlah laba maksimum yang dapat diperoleh pedagang tersebut! 


\section{Contoh 4: Butir skala diposisi matematik}

Keterangan Ss Sering sekali Jr: Jarang
\begin{tabular}{|c|l|c|c|c|c|}
\hline Sr Sering & \multicolumn{1}{|c|}{ Kegiatan dan pendapat Jarang sekali } & Ss & Sr & Jr & Jrs \\
\hline 1. & Yakin dapat menyelesaikan ulangan matematika. & & & & \\
\hline 2. & Bosan mengikuti pelajaran matematika & & & & \\
\hline 3. & Takut mengemukakan pendapat ketika diskusi matematika & & & & \\
\hline 4. & Belajar matematika dari berbagai sumber & & & & \\
\hline 5. & Senang membantu teman dalam belajar matematika & & & & \\
\hline 6. & Konsentrasi menurun ketika belajar matematika & & & & \\
\hline 7. & $\begin{array}{l}\text { Menunggu bantuan ketika mengalami kesulitan belajar } \\
\text { matematika }\end{array}$ & & & & \\
\hline
\end{tabular}

\section{Temuan dan Pembahasan}

Hasil analisis mengenai pretes, postes, dan normal gain kemampuan pemahaman, dan disposisi siswa tersaji pada Tabel 1. Berdasarkan data pada Tabel 1, diperoleh tidak ada perbedaan skor pretes kemampuan pemahaman matematik dan kemampuan komunikasi matematik siswa pada kedua kelas pembelajaran dan seluruhnya tergolong sangat rendah. Namun setelah pembelajaran, siswa kelas pembelajaran kontekstual dan strategi formulate-share-listen-create, kemampuan pemahaman matematik siswa mencapai (13,50 dari 20) dan memperoleh peningkatan $(0,61)$ yang tergolong sedang dan lebih baik daripada pencapaian $(11,08$ dari 20$)$ dan peningkatan $(0,48)$ siswa pada kelas konvensional yang tergolong kurang dalam kemampuan pemahaman matematik. Hasil serupa juga ditemukan, setelah pembelajaran, dalam kemampuan komunikasi matematik, siswa pada kelas pembelajaran kontektual dan strategi formulate-share-listen-create (FSLC) mencapai (16,98 dari 24) yang tergolong cukup dan memperoleh peningkatan $(0,68)$ yang lebih baik daripada pencapaian (11,08 dari 20) dan peningkatan $(0,48)$ siswa pada kelas konvensional yang tergolong kurang.

\section{Tabel 1}

Pretes, Postes dan N-Gain Kemampuan Pemahaman, Komunikasi, dan Disposisi Matematik Siswa pada Kedua Kelas Pembelajaran

\begin{tabular}{|c|c|c|c|c|c|c|c|c|c|c|c|c|c|c|}
\hline \multirow{3}{*}{$\begin{array}{l}\text { Kem. } \\
\text { Mat. }\end{array}$} & \multirow{3}{*}{$\mathbf{n}$} & \multirow{3}{*}{ SMI } & \multicolumn{6}{|c|}{ Kelas formulate-share-listen-create } & \multicolumn{6}{|c|}{ Kelas Konvensional } \\
\hline & & & \multicolumn{2}{|c|}{ Pretes } & \multicolumn{2}{|c|}{ Postes } & \multicolumn{2}{|c|}{ N-Gain } & \multicolumn{2}{|c|}{ Pretes } & \multicolumn{2}{|c|}{ Postes } & \multicolumn{2}{|c|}{ N-Gain } \\
\hline & & & $\bar{x}$ & $s$ & $\bar{x}$ & $s$ & $\boldsymbol{G}$ & $s$ & $\bar{x}$ & $s$ & $\bar{x}$ & $s$ & $G$ & $s$ \\
\hline $\begin{array}{l}\text { Pmh. } \\
\text { Mat }\end{array}$ & 40 & 20 & 3,55 & 1,87 & 13,50 & 2,71 & 0,61 & 0,16 & 2,88 & 1,76 & 11,08 & 2,65 & 0,48 & 0,16 \\
\hline $\begin{array}{c}\text { Kom. } \\
\text { Mat }\end{array}$ & 40 & 24 & 4,83 & 1,58 & 16,98 & 2,77 & 0,68 & 0,13 & 4,90 & 1,75 & 14,28 & 2,09 & 0,49 & 0,13 \\
\hline $\begin{array}{l}\text { Dis } \\
\text { Mat }\end{array}$ & 40 & 120 & & & 82,80 & 6,00 & & & & & 75,90 & 6,60 & & \\
\hline
\end{tabular}


Analisis asosiasi antara kemampuan pemahaman dan komunikasi matematik menggunakan tabel kontigensi seperti pada Tabel 2. Berdasarkan data pada Tabel 2 diperoleh asosiasi cukup antara kemampuan pemahaman dan komunikasi matematik. Data pada Tabel 2 menunjukkan tugas komunikasi matematik cenderung sedikit lebih sulit daripada tugas pemahaman matematik. Keadaan tersebut antara lain karena dalam tugas komunikasi matematik siswa selain harus memahami konsep juga harus dapat menjatakan konsep yang bersangkutan dalam bentuk matematika lainnya, dan memuat pula tugas menyatakan suatu model matematika ke dalam bentuk masalah sehari-hari. Pada pembelajaran matematika yang biasa tugas tersebut sangat jarang dilatihkan, dan siswa terbiasa dengan tugas yang langsung menerapkan rumus. Temuan tentang tugas matematik yang lebih sukar dari pada tugas pemahaman matematik juga serupa dengan temuan Emay (2011), Kurniawan (2010), Permana (2011) dan Setiadi (2010).

Tabel 2

Asosiasi antara Kemampuan Pemahaman dan Komunikasi Matematik Siswa pada Pembelajaran Kontekstual dan Strategi FSLC

\begin{tabular}{|c|c|c|c|c|}
\hline Pmh. Mat. & Rendah & Sedang & Tinggi & Total \\
\hline Rendah & 4 & 2 & 0 & 6 \\
\hline Sedang & 1 & 8 & 4 & 13 \\
\hline Tinggi & 2 & 7 & 12 & 21 \\
\hline Total & 7 & 17 & 16 & 40 \\
\hline
\end{tabular}

Catatan: Pmh. Mat. Pemahaman matematik

Kom. Mat. Komunikasi matematik

Gambaran disposisi matematik siswa kelas pembelajaran kontektual dan strategi formulate-share-listen-create dijaring melalui skala disposisi matematik dengan pilihan jawaban sangat sering, sering, jarang dan jarang sekali. Temuan menunjukkan diposisi matematik siswa pada kelas pembelajaran kontektual dan strategi formulate-share-listen-create berada pada katagori cukup baik (82,80 dari 120), atau tergolong positif dan ini lebih baik dari disposisi siswa pada kelas konvensional yang tergolong sedang (75,9 dari 120) atau netral (75).Temuan tersebut hampir serupa dengan temuan pada beberapa studi lain (Sumarmo, Hidayat, Hamidah, Zulkarnaen, Ratnasariningsih, 2012, Sumaryati 2012) yang menggunakan skala aspek afektif dengan pilihan jawaban dalam bentuk frekuensi. Namun dalam aspek afektif, temuan studi ini berbeda dengan temuan beberapa studi lainnya (Kurniawan, 2010, Permana, 2011, Yonandi, 2010) yang menggunakan skala disposisi dengan pilihan jawaban dalam derajat kesetujuan yang cenderung positif. 


\section{Kesimpulan dan Saran}

Berdasarkan temuan dan pembahasannya, penelitian ini memberikan kesimpulan sebagai berikut:

Kemampuan pemahaman matematik siswa dengan pembelajaran kontekstual dan strategi formulate-share-listen-create tergolong cukup baik, dan kemampuan tersebut lebih baik dibandingkan kemampuan pemahaman matematik siswa yang memperoleh pembelajaran konvensional yang tergolong sedang. Demikian pula peningkatan kemampuan pemahaman matematik siswa dengan pembelajaran kontekstual dan strategi formulate-share-listen-create lebih baik dari peningkatan kemampuan siswa pada kelas konvensional. Namun kedua peningkatan kemampuan pemahaman matematik tersebut sama-sama tergolong katagori sedang.

Keunggulan pembelajaran kontekstual dan strategi formulate-share-listen-create dari pembelajaran konvensional juga terjadi terhadap kemampuan komunikasi matematik. Siswa pada kelas eksperimen mencapai kemampuan komunikasi matematik yang tergolong sedang, dan kemampuan tersebut lebih baik dibandingkan kemampuan komunikasi matematik siswa yang memperoleh pembelajaran konvensional yang tergolong kurang. Demikian pula peningkatan kemampuan pemahaman matematik siswa dengan pembelajaran kontekstual dan strategi formulate-share-listen-create lebih baik dari peningkatan kemampuan siswa pada kelas konvensional. Namun kedua peningkatan kemampuan komunikasi matematik tersebut sama-sama tergolong katagori sedang.

Selain itu diperoleh pula kesimpulan bahwa terdapat asosiasi cukup antara kemampuan pemahaman dan komunikasi matematik pada kelas dengan pembelajaran kontekstual dan strategi formulate-share-listen-create. Namun, tugastugas pemahaman matematik dan komunikasi matematik tergolong relatif sukar bagi siswa SMK. Berkenaan dengan disposisi matematik, siswa pada kelas pembelajaran kontekstual dan strategi formulate-share-listen-create menunjukkan disposisi matematik yang tergolong cukup baik dan ini lebih baik dari diposisi matematik siswa pada kelas konvensional yang tergolong sedang.

Berdasarkan kesimpulan di atas, dikemukakan beberapa saran sebagai berikut. Penelitian ini dilaksanakan pada siswa SMK dengan kemampuan matematik siswa yang tergolong sedang. Mereka memerlukan waktu belajar yang lebih lama untuk memahami konsep-konsep matematika dan penerapannya. Terlebih lagi, soal-soal kemampuan pemahaman matematik dan komunikasi matematik dalam penelitian ini tergolong pada kemampuan matematik tingkat tinggi. Oleh karena itu disarankan pembelajaran dilaksanakan dalam waktu yang cukup untuk memberi kesempatan siswa belajar secara bermakna. 


\section{DAFTAR PUSTAKA}

Depdiknas. (2002). Pendekatan Kontekstual. Jakarta: Dikdasmen.

(2006). Kurikulum Tingkat Satuan Pendidikan SMK Edisi 2006. Jakarta: Dikmenjur.

Emay, A. (2011). Meningkatkan Kemampuan Pemahaman dan Komunikasi Matematis Siswa SMP dengan Menggunakan Pembelajaran Kooperatif Tipe Formulate-ShareListen-Create (FSLC). Tesis pada SPS UPI Bandung: Tidak diterbitkan.

Johnson, D. W., Johnson, R. T., \& Smith, K. A. (1991). Active Learning: Cooperation in the college classroom. Edina, MN: Interaction Book Company.

Kurniawan, R. (2010). Peningkatan Kemampuan Pemahanan dan Pemecahan Masalah Matematis Melalui Pembelajaran dengan Pendekatan Kontektual pada Siswa SMK. Disertasi pada SPS UPI Bandung: tidak diterbitkan.

Ledlow, S. (2012). Think Pair Share. [Online]. Tersedia: http://www.hydroville.org/system/files/team_thikpairshare.pdf

Lestari, P. (2009). Peningkatan Kemampuan Pemahaman dan Koneksi Matematis Siswa SMK melalui Pendekatan Pembelajaran Kontekstual. Tesis pada SPS UPI: tidak diterbitkan.

Nasir, S. (2008). Meningkatkan Kemampuan Koneksi dan Pemecahan Masalah Matematik Siswa SMA yang Berkemampuan Rendah melalui Pendekatan Kontekstual. Tesis pada PPS UPI: tidak diterbitkan.

NCTM. (2000). Principles and Standards for School Mathematics. Reston, VA : NCTM.

NCTM. [Online]. Tersedia: http://math-heyfun.blogspot.com/2010/12/komunikasi-ala$\underline{\text { nctm.html }}$

Permana, Y. (2011). Mengembangkan Kemampuan Pemahaman, Komunikasi, dan Disposisi Matematis Siswa Sekolah Menengah Atas Melalui Model-Eliciting Activities. Disertasi pada SPS UPI Bandung: tidak diterbitkan.

Riyanti, Sin. (2011). Jejak: Pemahaman Relasional. [Online]. Tersedia: http://sinriyanti.blogspot.com/2011/12/pemahaman-relasional.html

Sabilulungan. (2008). Pembelajaran Kooperatif dengan Teknik Think-Pair-Square (TPS) untuk Meningkatkan Kemampuan Penalaran dan Komunikasi Matematis Siswa SMP. Tesis pada SPS UPI: Tidak Diterbitkan.

Setiadi. (2010). Meningkatkan Kemampuan Pemahaman dan Komunikasi MAtematis Siswa SMP Melalui Pembelajaran Kooperatif dengan Teknik Think-Pair-Share. Tesis pada SPS UPI Bandung: tidak diterbitkan.

Sinau. (2012). (Komunikasi Ala NCTM) Aspek-aspek Kemampuan Komunikasi Matematika NCTM. [Online]. Tersedia: http://math-heyfun.blogspot.com/2010/12/komunikasiala-nctm.html

Sofian. (2011). Meningkatkan Kemampuan Pemahaman dan Penalaran Matematis Melalui Pembelajaran dengan Pendekatan Kontekstual. Tesis pada SPS UPI: tidak diterbitkan. 
Suherman, E., dkk. (2003). Strategi Pembelajaran Matematika Kontemporer. Bandung: Universitas Pendidikan Indonesia.

Sumarmo, U. (2010). Pendidikan Karakter, Berpikir dan Disposisi Logis, Kritis, dan Kreatif dalam Pembelajaran Matematika. Makalah disajikan dalam perkuliahan Evaluasi Matematika 2011 Pascasarjana UPI. Tidak Diterbitkan.

Sumarmo, U, Hidayat, W., Hamidah, Zulkaenaen, R., Ratnasariningsih. (2012). "Mengembangkan kemampuan dan disposisi berpikir logis, kritis, dan kreatif matematik siswa SMA melalui pembelajaran berbasis masalah dan strategi ThinkTalk-Write”. Jurnal Pengajaran MIPA, Vol. 17, No.1, 17-33, April 2012

Sumaryati, E. (2012). Pendekatan Induktif-Deduktif disertai Strategi Think-Pair-SquareShare untuk Meningkatkan Kemampuan Pemahamandan Berpikir Kritis Matematis Siswa SMA. Tesis pada SPS UPI: Tidak Diterbitkan.

Turmudi. (2009). Landasan Filsafat dan Teori Pembelajaran Matematika (Berparadigma Eksploratif dan Investigatif). Jakarta: Leuser Cita Pustaka.

Yonandi. (2012). Meningkatkan Kemampuan Komunikasi dan Pemecahan Masalah Matematik melalui Pembelajaran Kontekstual Berbantuan Komputer pada Siswa Sekolah Menengah Atas. Disertasi pada SPs UPI. 